\title{
Resistivity imaging survey of Capo Long Barrow, Aberdeenshire
}

\author{
by Lindsey Collier, Bruce Hobbs
}

Department of Geology and Geophysics, University of Edinburgh,

Grant Institute, Kings Buildings, Edinburgh EH9 3JW

\section{Tim Neighbour}

CFA Archaeology Ltd, Suite 2, Archibald Hope House, Eskmills Park, Musselburgh EH21 7PQ

$$
\text { and Richard Strachan }
$$

Historic Scotland, Longmore House, Salisbury Place, Edinburgh EH9 1SH

\author{
with a contribution by Graeme Warren \\ and illustrations by George Mudie
}


Published by the Society of Antiquaries of Scotland, www.socantscot.org with Historic Scotland

and the Council for British Archaeology

Editor Colin Wallace

Produced by Archetype Information Technology Ltd, www.archetype-it.com

ISBN: $090390375 \mathrm{X}$

ISSN: $1473-3803$ 


\section{Contents}

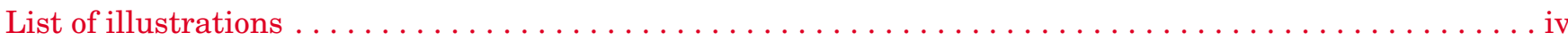

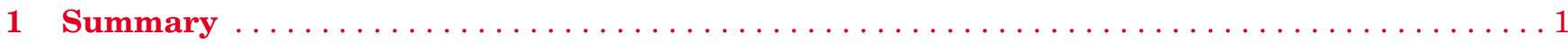

2 Introduction by Lindsey Collier, Bruce Hobbs, Tim Neighbour and Richard Strachan............. 3

3 Previous work by Lindsey Collier, Bruce Hobbs, Tim Neighbour and Richard Strachan . . . . . . . . . 5

4 Topographical survey by Lindsey Collier, Bruce Hobbs, Tim Neighbour and Richard Strachan . . . 6

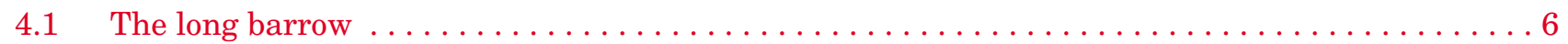

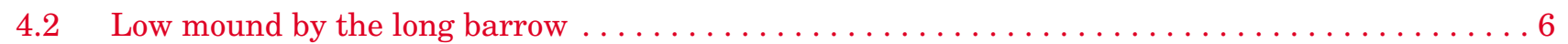

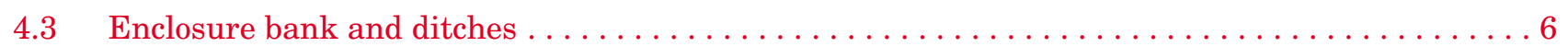

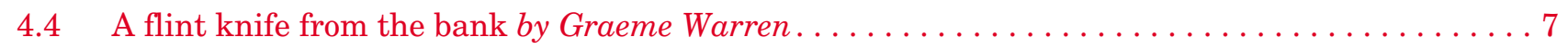

5 Geophysical survey by Lindsey Collier, Bruce Hobbs, Tim Neighbour and Richard Strachan . . . . . 8

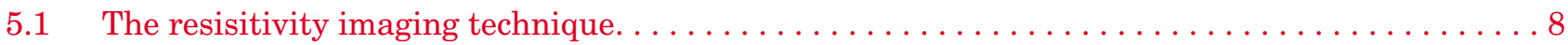

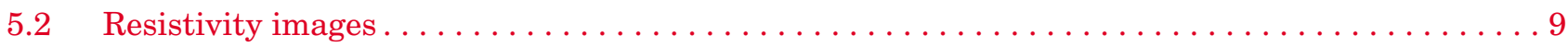

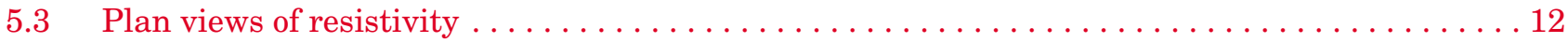

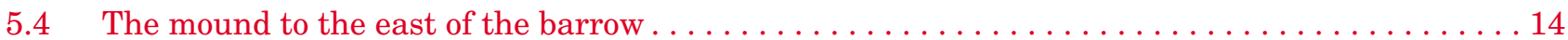

6 Conclusions by Lindsey Collier, Bruce Hobbs, Tim Neighbour and Richard Strachan . . . . . . . . . 15

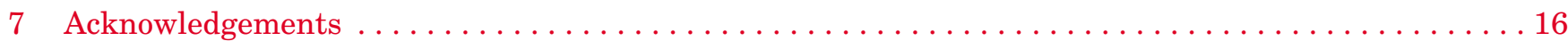

8 References ................................................... 17 


\section{List of illustrations}

Capo Barrow: location map. . . . . . . . . . . . . . . . . . . . 2

Capo Barrow: plan of the long barrow and enclosure.. . . . . . . . . . . . . . . . 4

Capo Barrow: (a) from the north, (b) from the south (photographs: Gordon Barclay). . . . . . . . 5

Capo Barrow: the plano-convex flint knife (scale $1: 1) \ldots \ldots \ldots \ldots$

Capo Barrow: (a) use of electrode sequences to obtain measurements at different

lateral positions; (b) use of electrode sequences to obtain measurements at different

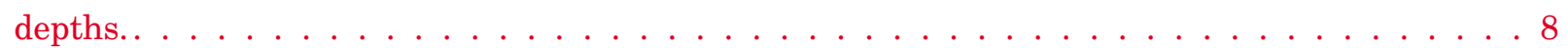

Capo Barrow: positions of resistivity profiles taken across the long barrow and the topography used in modelling the profiles. . . . . . . . . . . . . . . . . 9

Capo Barrow: Profile 34, apparent resistivities (no topographical correction); north at left side of plot. . . . . . . . . . . . . . . . . . . . . . 9

Capo Barrow: (a) Profile 34, measured apparent resistivities and topography used in modelling the profiles (scale altered to accommodate larger variations seen in the model [8c]); (b) Profile 34, apparent resistivities calculated from the model;

(c) Profile 34, modelled resistivity cross-section with true depth scale. North at left side of plots.. . . . . . . . . . . . . . . . . . . . . . . . . . 10

Capo Barrow: Profile 34: modelled resistivity cross-section, topographically corrected. North at left side of plot. . . . . . . . . . . . . . . . . . . . . . . . 10

Capo Barrow: Profile 32: modelled resistivity cross-section, topographically corrected.

North at left side of plot. . . . . . . . . . . . . . . . . . . . . . . . . . 11

Capo Barrow: Profile 21: modelled resistivity cross-section, topographically corrected.

North at left side of plot. . . . . . . . . . . . . . . . . . . . . . . . 11

Capo Barrow: Profile 15: modelled resistivity cross-section, topographically corrected.

North at left side of plot. . . . . . . . . . . . . . . . . . . . . . . . . . 12

Capo Barrow: Profile 12: modelled resistivity cross-section, topographically corrected.

North at left side of plot. . . . . . . . . . . . . . . . . . . . . . . . . . . 12

Capo Barrow: Horizontal depth slice through collated modelled images at a datum level of $-0.5 \mathrm{~m}$ (Scale $500 \Omega \mathrm{m}-5500 \Omega \mathrm{m})$. Presented by UNIMAP. . . . . . . . . . . . . . . . . 13

Capo Barrow: Horizontal depth slice through collated modelled images at a datum level of $-0.5 \mathrm{~m}$ (Scale $2000 \Omega \mathrm{m}-10,000 \Omega \mathrm{m}$ ). Presented by UNIMAP. . . . . . . . . . . . . . . . 13

Capo Barrow: Horizontal depth slice through collated modelled images at a datum level of $-1.5 \mathrm{~m}$ (Scale $300 \Omega \mathrm{m}-8000 \Omega \mathrm{m}$ ). Presented by UNIMAP. . . . . . . . . . . . . . . . . 14 Capo Barrow: horizontal depth slice through collated modelled images, including the small mound to the east of the barrow, at a datum level of $-0.5 \mathrm{~m}$ (Scale $2000 \Omega \mathrm{m}-$ $10,000 \Omega \mathrm{m})$. Presented by UNIMAP. . . . . . . . . . . . . . . . . . . . . . . 14 


\section{Summary}

Non-invasive fieldwork carried out on the Neolithic long barrow at Capo, present-day Aberdeenshire (NGR NO 633 664) has considerably enhanced our knowledge of this monument. Topographical survey has provided the first detailed record of the barrow and its environs. Resistivity imaging has revealed key elements of the structure of the long barrow, including side revetment walls, a flat façade and possible mortuary structures, confirming that the barrow at Capo is of a similar morphology to the nearby (excavated) long barrow at Dalladies. The resistivity survey has demonstrated that rabbit burrowing and the roots of the tree stumps that covered the barrow have had little effect on the integrity of the major structural elements of the monument (the revetments and façade). However, it is not possible to assess the more subtle damage, such as mixing of archaeological layers, which may have been caused. It is concluded that, whilst resistivity imaging at the survey density employed here is time-consuming and would not be appropriate at many sites, as a management tool and as a means to explore sites that are unavailable for excavation, such as scheduled ancient monuments, it has been demonstrated to be of considerable value. 

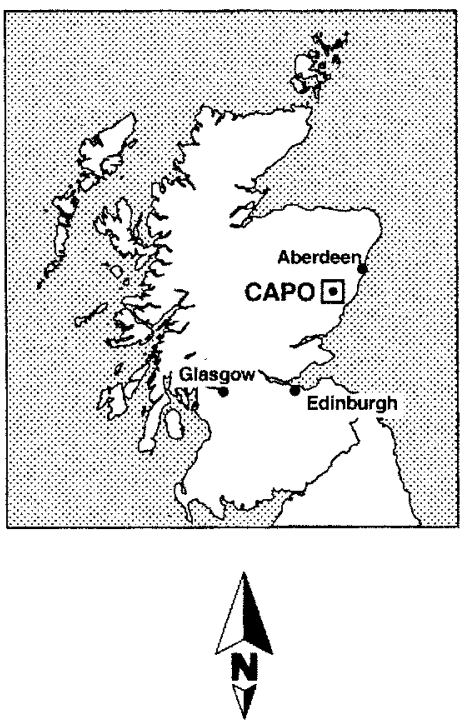
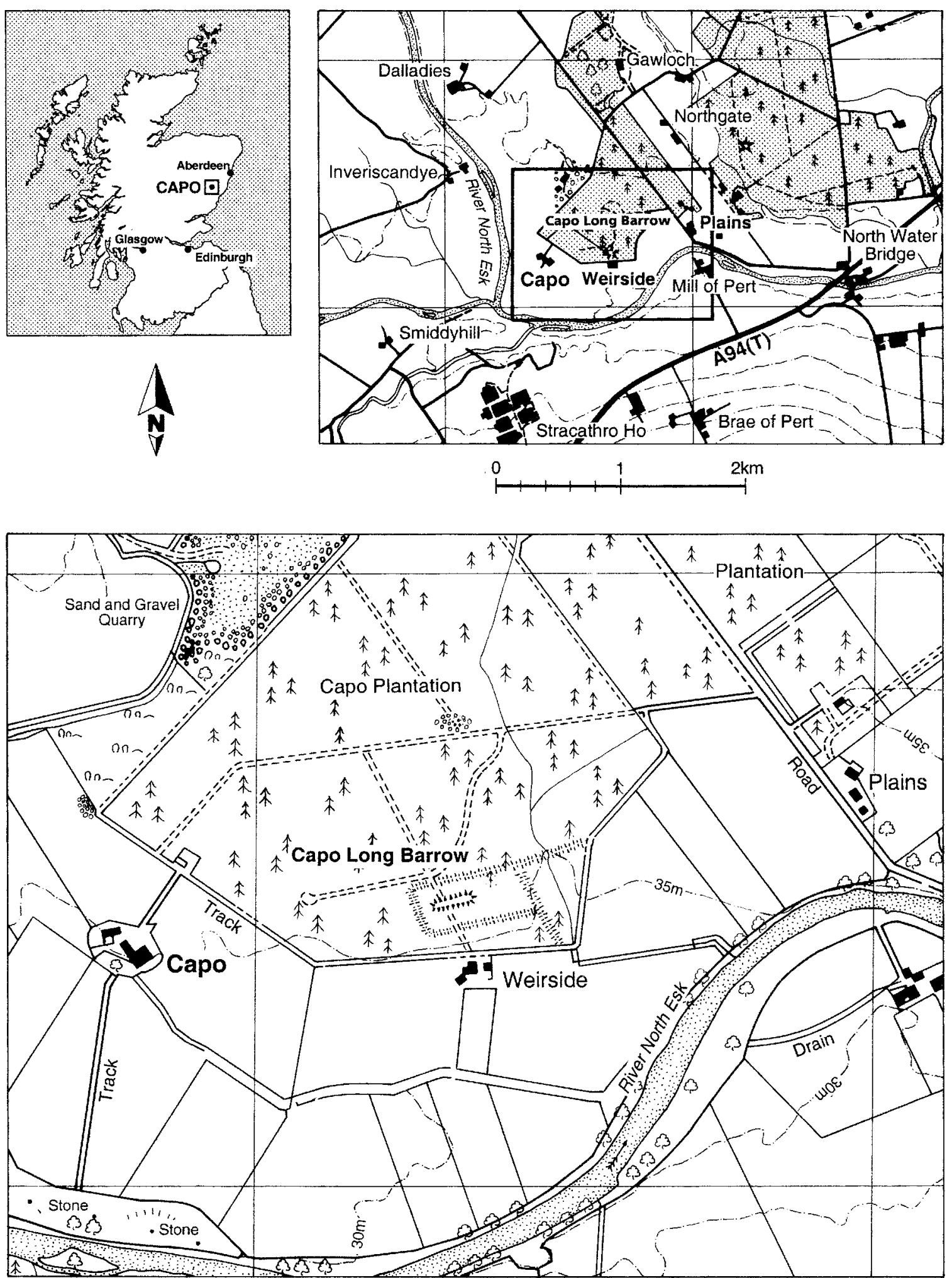

0

$500 \mathrm{~m}$

Illus 1 Capo Barrow: location map 


\section{Introduction by Lindsey Collier, Bruce Hobbs, Tim Neighbour and Richard Strachan}

This paper presents the results of topographical and geophysical survey carried out at Capo Long Barrow, Aberdeenshire [formerly Kincardineshire] (NGR NO 633 664; NMRS NO66NW 28; RCAHMS 1982; Henshall 1972, 562 [KNC9]). The work was carried out in 1998 and 1999 as part of The Angus and South Aberdeenshire Field School of the Department of Archaeology, University of Edinburgh (Finlayson et al 1999) in collaboration with the University's Department of Geology and Geophysics. The Project Archive will be deposited in due course with the NMRS in Edinburgh. The flint knife and a small secondary chunk of yellow pebble flint recovered in 1999 (Section 4.4) will be allocated by Historic Scotland's Finds Disposal Panel.

Neolithic long barrows are generally trapezoidal in shape and often contain one or more mortuary structures (Kinnes 1992; Lynch 1997). Regional variations to the standard components of a long barrow have long been recognised (ibid). Capo Long Barrow lies only a mile away from the Dalladies Long Barrow, which was excavated in 1970/71 (Piggott 1974). A stone mortuary structure, four secondary stone cists, stone side-revetments and a substantial façade were revealed (ibid, fig 3 ). It was anticipated that the internal structure at Capo would be similar to that at Dalladies and thus would form a useful test site for a resistivity imaging survey. Furthermore, the resistivity survey provided a means by which to assess the damage caused to the barrow by rabbit burrowing and the roots of the trees that formerly covered the barrow. 


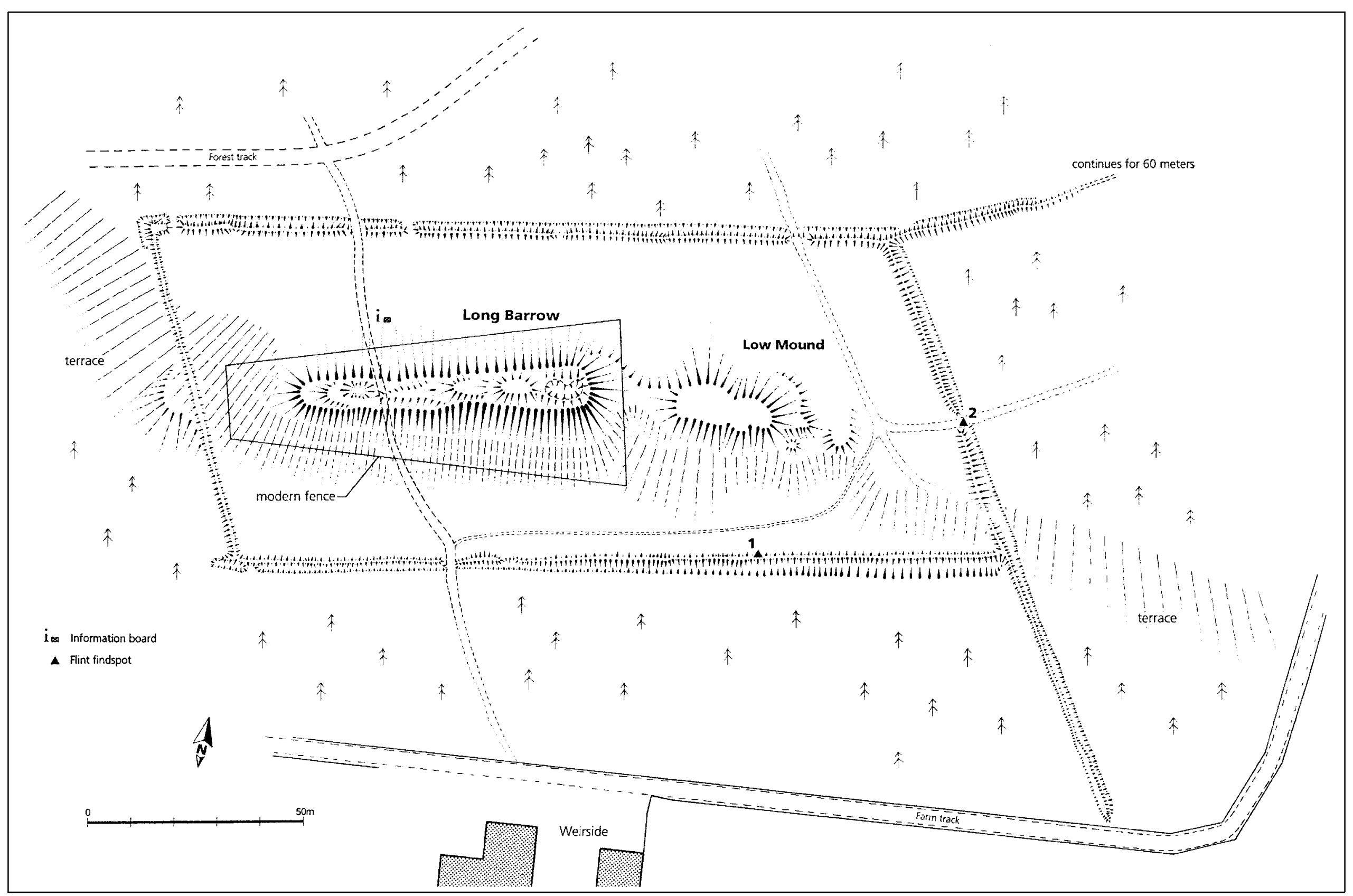

Illus 2 Capo Barrow: plan of long barrow and enclosure 


\section{Previous work by Lindsey Collier, Bruce Hobbs, Tim Neighbour and Richard Strachan}

Capo Long Barrow is situated in a clearing near the southern boundary of Capo Plantation $c 0.5 \mathrm{~km}$ north of the River North Esk (Illus 1). The barrow was first identified by Dr W Dally of Edzell and the Arbroath Antiquary Club in 1968 (Piggott 1970; Henshall 1972, 562). A survey was carried out in September 1970 while the barrow was still under tree cover. A contour plan, one longitudinal and five transverse profiles of the mound were produced. These pencil drawings are archived in the NMRS and have never been published.

The undergrowth of small trees and shrubs surrounding and covering the long barrow was cleared by the Association of Certificated Field Archaeologists (ACFA), prior to their survey of a parallelogram enclosure that surrounds the barrow, in 1990. Their drawings, however, were never completed (pers comm $\mathrm{S}$ Wood). They too have been archived in the NMRS.

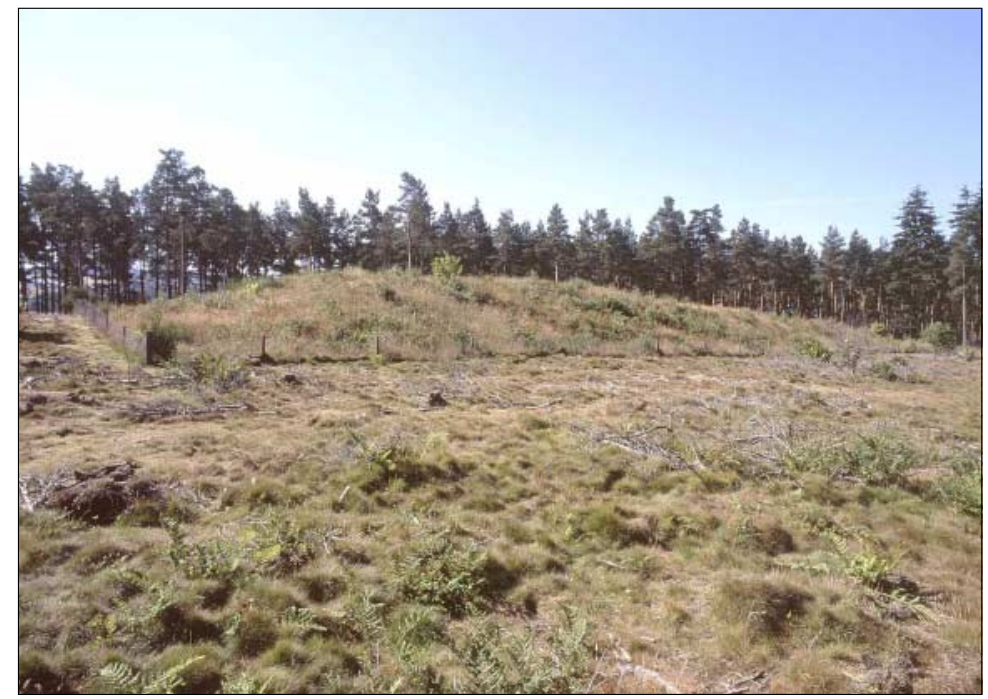

$3 \mathrm{a}$

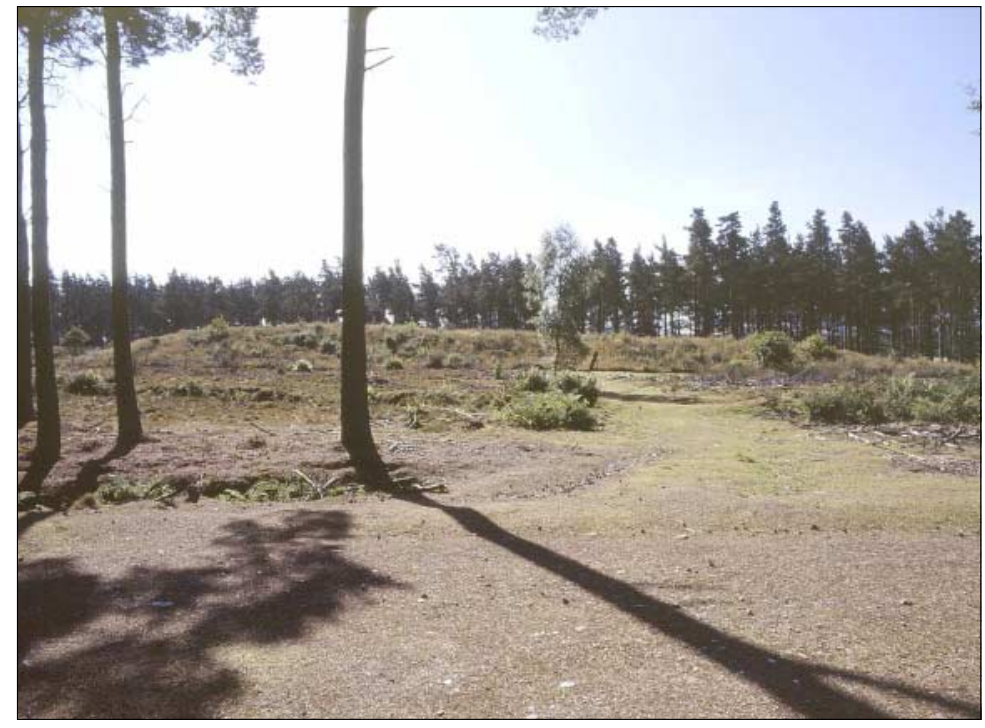

$3 b$

Illus 3 Capo Barrow: (a) from the north, (b) from the south (photographs: Gordon Barclay) 


\section{Topographical survey by Lindsey Collier, Bruce Hobbs, Tim Neighbour and Richard Strachan}

The first detailed survey work was carried out over four days in April 1999 as part of The Angus and South Aberdeenshire Field School. Four components were identified including a natural terrace, the long barrow, a low mound to the east of the long barrow and a trapezoidal enclosure system of banks and ditches enclosing the barrow and mound (Illus 2).

\subsection{The long barrow}

The barrow (illus 3) is situated on the southern edge of a natural terrace, on the boundary between alluvial soils of recent riverine and lacustrine alluvial deposits and the Corby/Boyndie/Dinnet series of fluvio-glacial and raised beach sands and gravels derived from acid rocks (according to the 1981 Soil Survey of Scotland (Eastern Scotland). 1:250,000 map; Walker et al 1982, $45-47 \& 76-77)$. The terrace edge is a steep slope of $c 2.7-4.0 \mathrm{~m}$ in height. It runs on a roughly east to west alignment. Modern drainage ditches run along the base of the western edge of the terrace. With the exception of the terrace, forestry and quarrying modifications, the surrounding terrain is flat.

The barrow lies with its main axis at $77^{\circ}$ east of north. It is trapezoidal, with its broader and higher end facing east. The southern and south-western sides of the mound continue the slope of the natural terrace, with no visible distinction between terrace and mound, with the exception that where both mound and terrace are present, the gradient of slope is greatly increased. When viewed from the south, this presents the illusion of considerable height to the mound.

The mound measures $87 \mathrm{~m}$ in length by $31.5 \mathrm{~m}$ wide at its eastern end, tapering to $16 \mathrm{~m}$ at the west. The summit of the barrow is generally flat, between $4 \mathrm{~m}$ and $7.5 \mathrm{~m}$ wide, and slopes gently downwards from east to west. The eastern end of the barrow stands $c 2.5 \mathrm{~m}$ above the ground level to the north and over $4.5 \mathrm{~m}$ above the base of the terrace. The western end of the barrow stands $c 1.6 \mathrm{~m}$ above the ground level to the north, and $3.8 \mathrm{~m}$ to the south, above the base of the terrace. The base of the terrace to the west of the mound is $2.4 \mathrm{~m}$ below its western summit.

The cover of the mound is predominantly grass, tree-stumps, moss and bracken, forest debris and rosebay willow-herb. Rabbit burrows and tree-bole holes are present all over the mound.

A linear depression $c 3.2 \mathrm{~m}$ wide runs across the northern face and summit of the monument approximately one third along its length from the western end. This depression, which has caused some localised deflation to the summit of the monument, is clearly indicative of relatively recent traffic over the mound. The depression corresponds to breaks in the enclosure bank to the north and south, and to the forestry track depicted on the current Ordnance Survey map and possibly on the Ordnance Survey Second Edition 6" to 1 mile map of 1904 (Kincardineshire, Sheet XXIXNE, revised from the First Edition in 1901).

An area of deflation, measuring $c 8 \mathrm{~m}$ east-west by $5 \mathrm{~m}$ transversely, lies upon the eastern summit of the mound. This deflation appears to be the result of subsidence of some internal structure within the mound; perhaps a mortuary structure similar to that identified at Dalladies (Piggott 1974, 30-36 \& fig 4).

No external stones or structural components are visible within the mound material. There are no surface indications of external ditches running parallel to the sides of the barrow, as were discovered at Dalladies (Piggott 1974, 26-27 \& fig 3).

\subsection{Low mound by the long barrow}

A low mound lies immediately to the east of the long barrow, situated on the edge of the same terrace. Like the barrow, it is covered in grass, tree-stumps and numerous uprooted trees. The mound measures $c 45 \mathrm{~m}$ east-west by $15 \mathrm{~m}$ transversely and stands $c 1.5 \mathrm{~m}$ above the ground level to the north. The western edge of the mound appears to run into the base of the eastern end of the long barrow. To the north, the edge of the mound is irregular and poorly defined. The relationship between the mound and the long barrow cannot be established on the basis of surface evidence and the function of the mound is not readily apparent. Possibilities include:

1. that the mound may be a natural part of the terrace;

2. that the mound may be an earlier monument partially robbed to construct the long barrow;

3. that the mound may be a secondary funerary monument;

4. that the mound may be spoil, either from previous investigations into the barrow, or associated with early 20th-century quarry workings, located to the south-east.

\subsection{Enclosure bank and ditches}

The long barrow and low mound are surrounded by a series of rectilinear banks and ditches which form a trapezoidal enclosure, with banks projecting from the north-eastern, south-eastern and south-western corners of the mound. Banks and ditches, similar to 
those around the barrow, have also been located elsewhere within Capo Plantation (Barclay and Shepherd 1989) and are considered most likely to have been constructed at the time the Plantation was established.

\subsection{Two flints from the vicinity of the Capo Long Barrow by Graeme Warren}

Two flints were recovered from eroded parts of the earthen banks of the enclosure around the barrow in 1999 (Illus 2, Findspots 1 and 2). A further two flint flakes had some years previously been picked up on the barrow itself (Barlow and Geldart 1978): these are not described here. Of the two recovered in 1999, one is a small secondary chunk of yellow pebble flint $(14 \times 8 \times 5 \mathrm{~mm}$; no. 2 on Illus 2$)$, probably a by-product of a knapping episode, and the other is a broken fragment of an unusual plano-convex flint knife $(48 \times 21$ $\times 6 \mathrm{~mm}$; no. 1 on Illus 2 ; Illus 4 ).

The knife fragment has been manufactured on mottled yellow-grey flint. This flint is unlikely to be local, although in the absence of greater contextual understanding of flint sources in the area it is impossible to be certain. The distal edge of the knife survives and shows neat invasive pressure flaking from one edge, forming parallel removal scars across the dorsal surface. The other side of the knife has less distinct percussive evidence, partly because of a large area of coarse flint, but removals are still discernible. Both edges have also received short $(2-3 \mathrm{~mm})$ edge-modification; in places this is somewhat uneven. The distal end of the knife has been retouched by short blunting and larger removals into a light 'tang'; a very unusual feature. Some planoconvex knives have been found with distinctive wear traces (Piggott \& Powell 1951, 121/128): the Capo example does not demonstrate this macroscopically.

Such knives are not chronologically diagnostic, being found with a range of, typically funerary, associations throughout the Neolithic and Early Bronze Age (contra Clark 1932). They have been found with chambered tombs and leaf-shaped arrowheads (Bryce 1903) and in individual burials with Food Vessels and metal daggers (Clark 1932, using English and Welsh evidence). They are most often found in association with funerary monuments and it has been argued that in Yorkshire they were manufactured specifically for funerary purposes (Pierpoint 1980). In Scotland they are often found with tombs of the Clyde type and have also been found at earthen long barrows, such as Dalladies (Piggott 1974, 38 \& fig 13.1). Here an example $133 \mathrm{~mm}$ in length was found in association with the wooden mortuary structure underlying the mound. This complete artefact was manufactured on mottled grey flint, argued to derive from Yorkshire, and was retouched only on one surface. It is pressure retouched and narrow towards the distal. It was seemingly deliberately deposited in association with
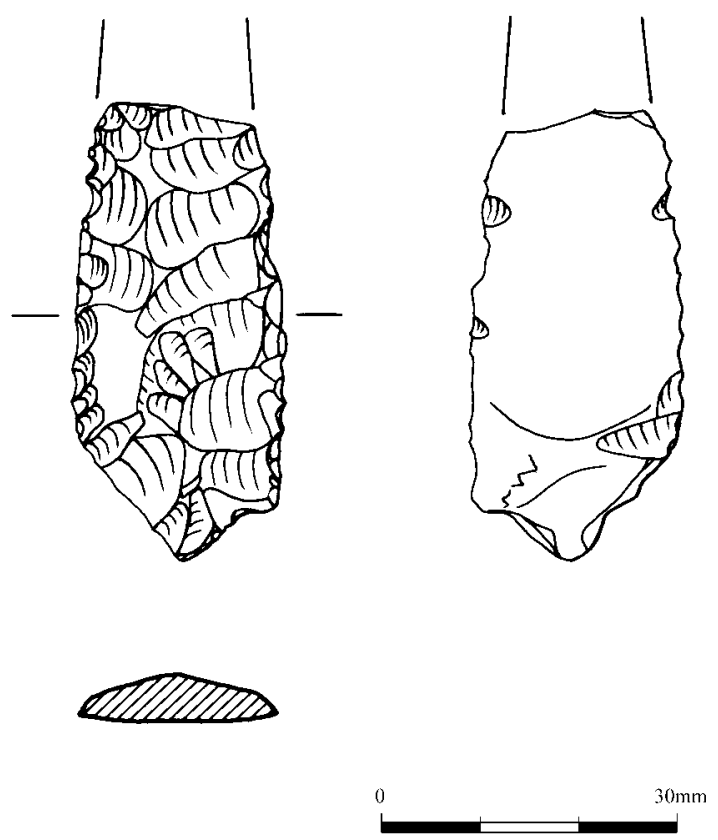

Illus 4 Capo Barrow: the plano-convex flint knife (scale 1:1)

Phase 1 and Phase 2 activity on the site (it is not possible to attribute this artefact with one phase of activity). Dates for the burning and abandonment of Dalladies Phase 2 of 3700 to 3000 cal BC (SRR-289) and 3650 to 2900 cal BC (SRR-290) provide a terminus ante quem for its deposition (dates are quoted at 2-sigma confidence from Historic Scotland's recalibration of Piggott's dates [Piggott 1974, 26], available on-line at www.historic-scotland. gov.uk).

The Capo example is unusual. It is quite a small knife, which appears to narrow towards the proximal, and its distal tang is a distinctive feature. However, even these distinctive features do not help us to date the artefact more closely. Henshall noted the variety of forms of plano-convex knives in Scottish burial contexts, stating that 'plano-convex knives cannot be classified closely nor fitted into a chronological category' (Henshall 1972, 186) and it seems that the Capo knife offers us little more indication of date than Neolithic to Early Bronze Age. It is certainly tempting to associate it with the same period as the activity at Dalladies, but this must remain conjectural. Plano-convex knives are found most frequently in immediately funerary contexts and the presence of the knife in the later bank surrounding the barrow may be indicative of disturbance to the barrow, or, more tentatively, of the disturbance of inhumations or mortuary activity in the area surrounding the barrow. Broken planoconvex knives are also rare: one burnt example was recovered from Blackhammer (Henshall 1963, 110), but more often the knives are complete. The incomplete character and the presence of some edge damage on the break facet of the Capo example may be more evidence of considerable disturbance to the original context of this fine artefact. 


\section{Geophysical survey by Lindsey Collier, Bruce Hobbs, Tim Neighbour and Richard Strachan}

Various geophysical prospection techniques are applicable to specific archaeological problems (Clark 1996). Whilst area resistivity and gradiometry surveys have been used with some success to record ploughed-out long barrows (Marshall 1998), these techniques would have been logistically difficult in the terrain at Capo. Furthermore, as the main aim of the project was to attempt to reveal internal structure, a technique that would provide depth information was required. Capo Long Barrow is covered with tree stumps and bracken and was considered to be inaccessible for a ground-penetrating radar survey. However, the success of resistivity imaging conducted on the banks and ditches at the Mull of Galloway (Neighbour et al 2001) suggested that resistivity profiling would also prove useful at Capo Long Barrow. The survey was undertaken with the particular goals of testing the hypothesis that the internal structure of the barrow was similar to that at the nearby, excavated long barrow at Dalladies (Piggott 1974) and attempting to assessing the level of damage that had been caused to the barrow by rabbit burrowing and tree roots. The data at Capo was collected by Lindsey Collier over twenty days in September 1999.

\subsection{The Resistivity imaging technique}

In the resistivity imaging technique (e.g. Loke and Barker 1995), a number of electrodes (in our case 25 or 32) are equi-spaced along a profile and connected via a multi-core cable to a resistivity meter and a laptop computer. The selection of electrodes (generally two current electrodes and two potential electrodes) and the subsequent resistivity measurement is made under software control. For the Capo survey the Wenner electrode array was used throughout, whereby four equi-spaced electrodes are selected (Illus 5a). Current is passed through the outer two and the potential difference measured between the inner two, enabling apparent resistivity to be determined for the given spacing and electrode array position along the profile. A pseudo-section may be generated by assigning the value of the measured apparent resistivity to a location corresponding to the centre point of the 4-electrode array at a nominal depth of half the electrode spacing. Using a multicore cable with electrodes equally spaced a distance $a$ apart along a line, the software selects all the Wenner configurations with electrode spacing $a$,

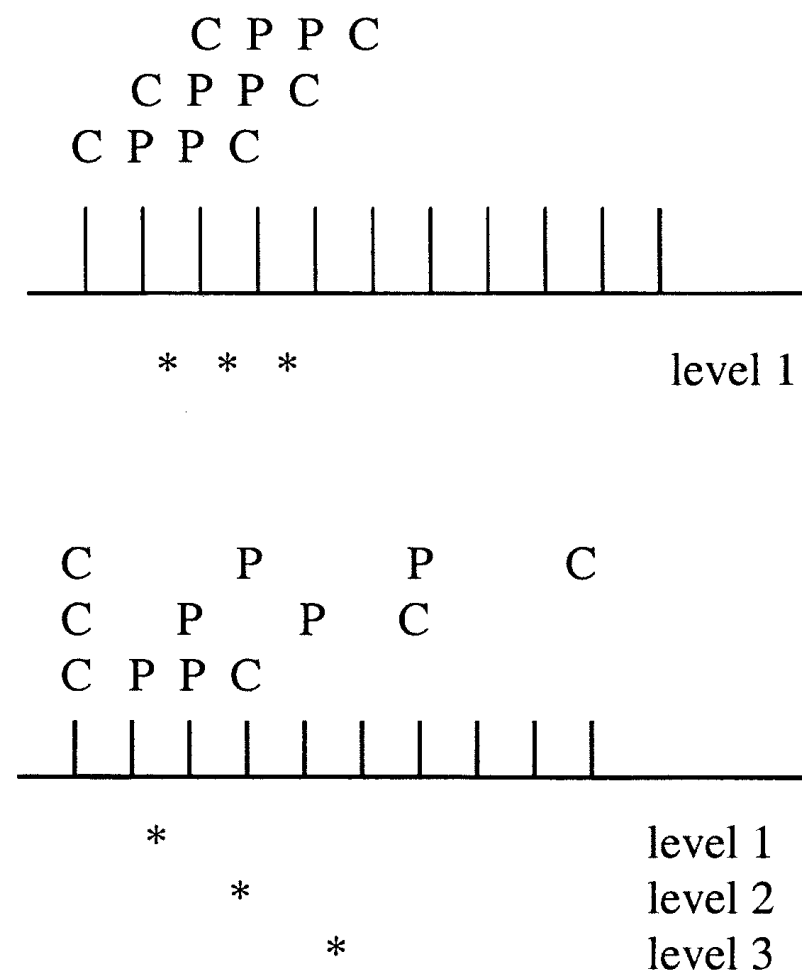

Illus 5 Capo Barrow: (a, above) use of electrode sequences to obtain measurements at different lateral positions; ( $b$, below) use of electrode sequences to obtain measurements at different depths. 


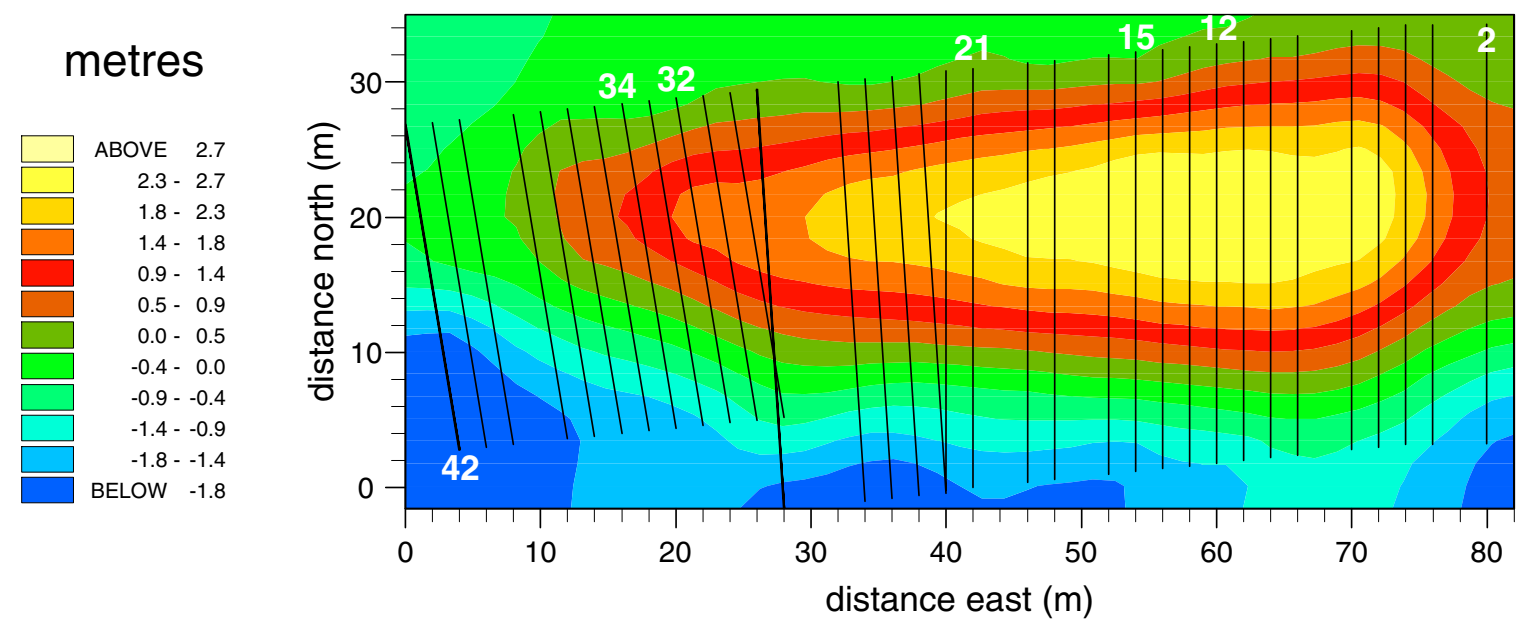

Illus 6 Capo Barrow: positions of resistivity profiles taken across the long barrow and the topography used in modelling the profiles

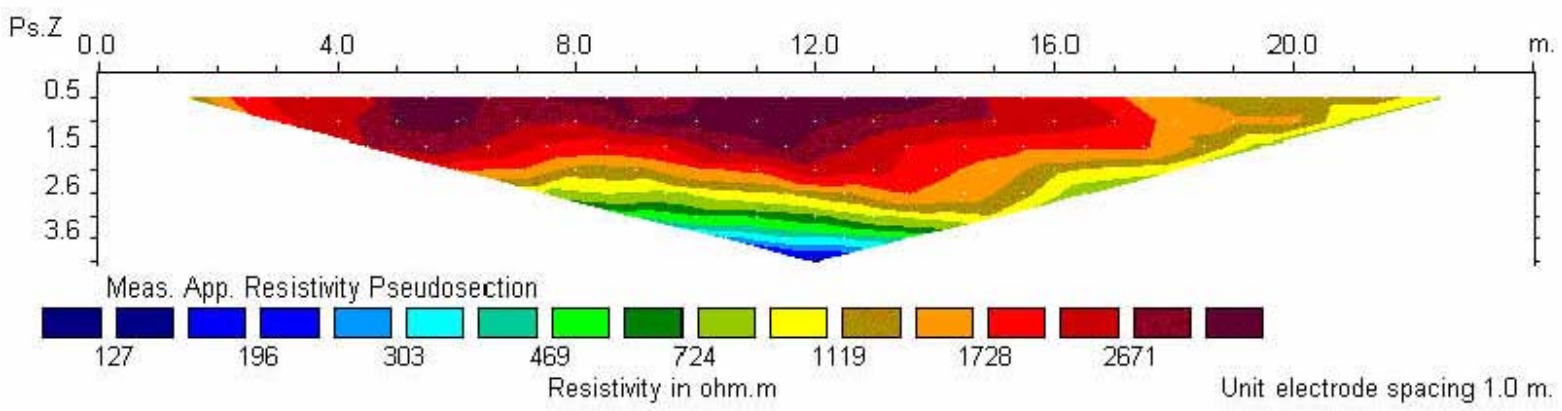

Illus 7 Capo Barrow: Profile 34, apparent resistivities (no topographical correction); north at left side of plot

then all those with electrode spacing $2 a$ (providing deeper information) and continues to a spacing of $8 a$ for a 25-electrode system. This yields a triangular vertical cross-section of apparent resistivity beneath the profile (Illus 5b). By moving some electrodes along the profile, a trapezoidal region can be obtained. Electrode spacings for the Capo survey varied between $1 \mathrm{~m}$ and $8 \mathrm{~m}$, yielding resistivity information to a depth of approximately $4 \mathrm{~m}$.

Measured apparent resistivities have then to be inverted to determine a model of the resistivity structure beneath the profile. Where a profile is not along a flat surface, the topographic relationships between the electrodes have to be taken into account. The two-dimensional inversion package 'RES2DINV', which includes the effects of topography, was used throughout.

\subsection{Resistivity images}

Forty-eight profiles were surveyed across the barrow and the small mound to its east. Illus 6 shows the positions of the 35 resistivity profiles taken across Capo Long Barrow, together with the topography used in modelling the images. The electrode separation was $1 \mathrm{~m}$ and the profiles were generally spaced $2 \mathrm{~m}$ apart, although this was not always possible, due to having to place the line so that it avoided tree stumps. Measuring tapes were used to locate the profiles and individual electrodes. Profiles are labelled to indicate their position along the barrow. The positions of those profiles on which "bad data' were recorded are not shown.

Selected images from positions $34,32,21,15$ and 12 (Illus 7-13) have been used to illustrate some of the main features seen in the vertical cross-sections and then an alternative way of viewing the data has been presented.

Illus 7 shows the apparent resistivity measured along profile 34 at the narrower, western end. The profile length is $24 \mathrm{~m}$ and the depth scale is pseudodepth (i.e. resistivities are plotted at half the electrode spacing). High resistivity regions can be seen at about $5 \mathrm{~m}$ and $12 \mathrm{~m}$ along the profile and the deeper regions are more conducting. These apparent resistivities have to be inverted to obtain modelled resistivities with a true depth scale. Inversion is achieved using 'RES2DINV' and account is taken of the topographic positions of the electrodes. RES2DINV accepts electrode positions as measured along the surface and these are estimated to be 
(a)

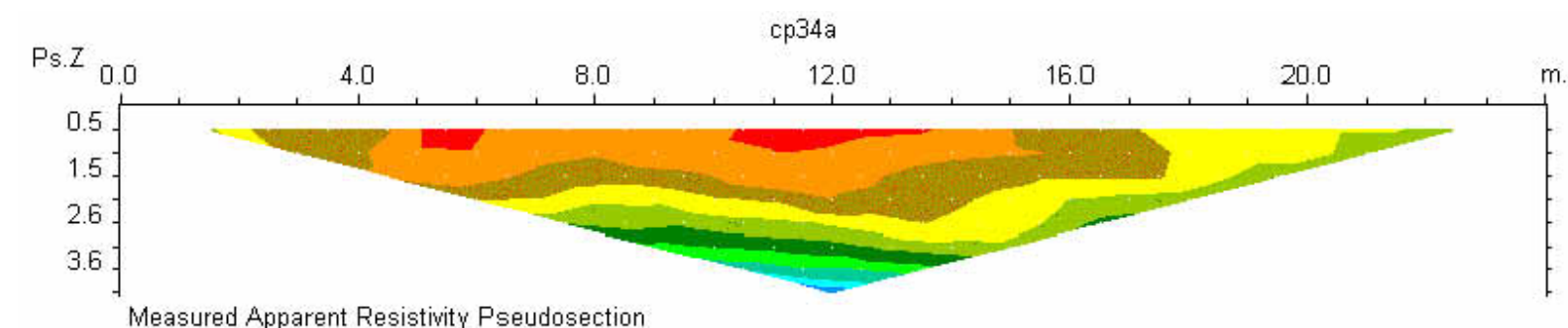

(b)

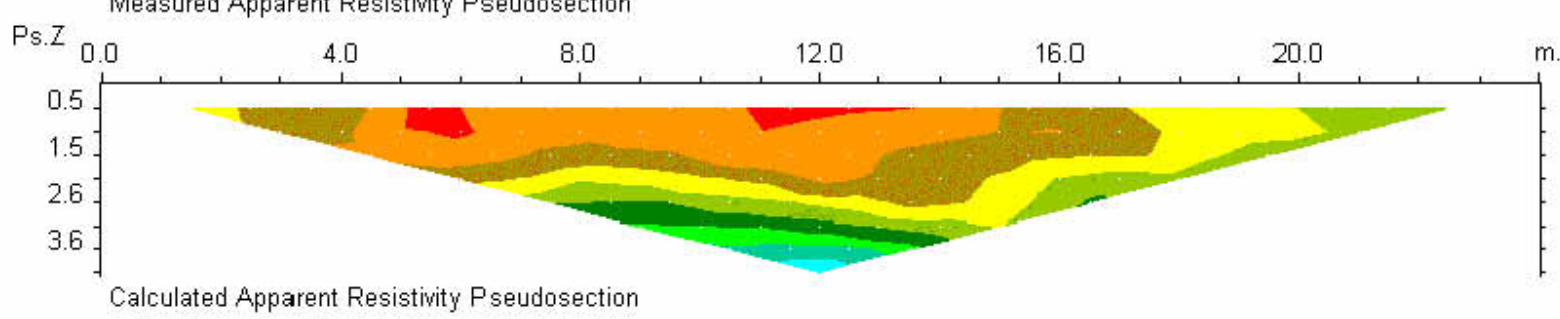

(c)

Depth Iteration 5 RMS error $=8.8 \%$

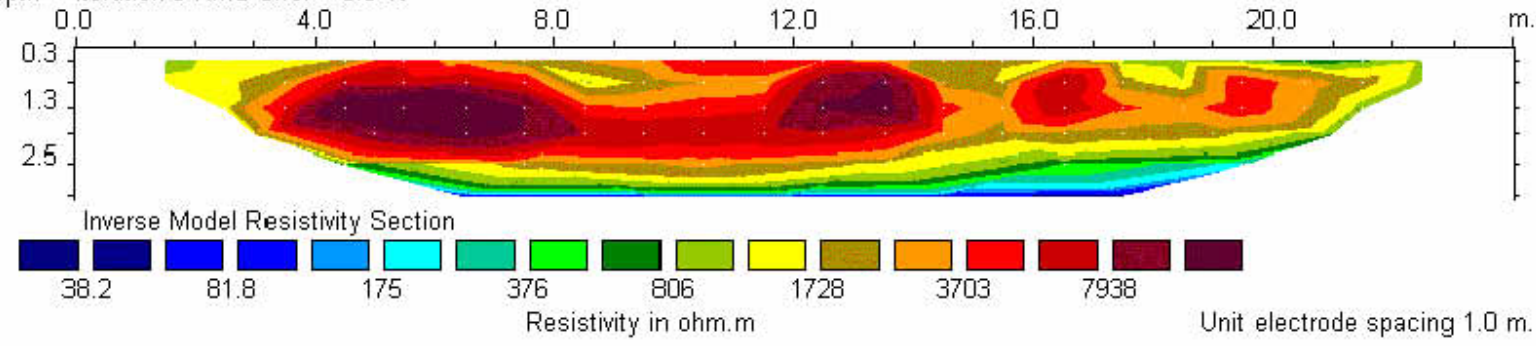

Illus 8 Capo Barrow: (a) Profile 34, measured apparent resistivities and topography used in modelling the profiles (scale altered to accommodate larger variations seen in the model [8c]); (b) Profile 34, apparent resistivities calculated from the model; (c) Profile 34, modelled resistivity cross-section with true depth scale. North at left side of plots

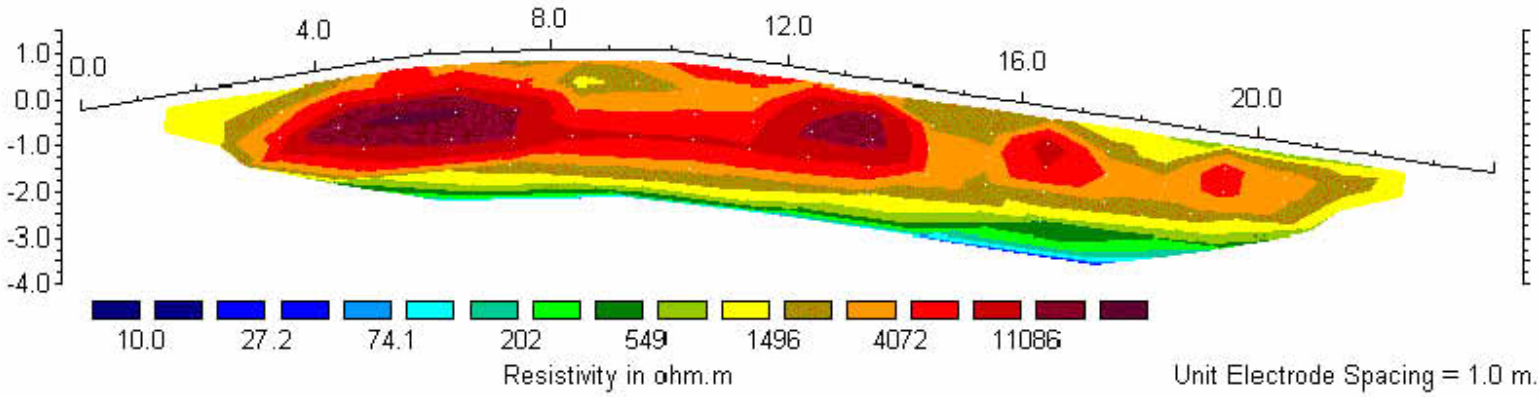

Horizontal scale is 30.42 pixels per unit spacing

Vertical exaggeration in model section display $=0.77$

First electrode is located at $0.0 \mathrm{~m}$.

Last electrode is located at $24.0 \mathrm{~m}$.

Illus 9 Capo Barrow: Profile 34: modelled resistivity cross-section, topographically corrected. North at left side of plot

accurate to $20 \mathrm{~mm}$ within an individual Wenner array. This yields an uncertainty of at most $2 \%$ (for near surface apparent resistivities), which is comparable to the instrument measurement error demanded on acquisition and is negligible in comparison to the two orders of magnitude variation in the range of resistivities encountered. Illus 8(a) shows the original measured apparent resistivities, but with a resistivity scale change to accommodate the larger variations seen in the model; Illus 8 (b) shows the apparent resistivities calculated from this model; and Illus 8(c) shows the resulting modelled resistivity cross-section with true depth scale. The calculated apparent resistivities compare reasonably well with 


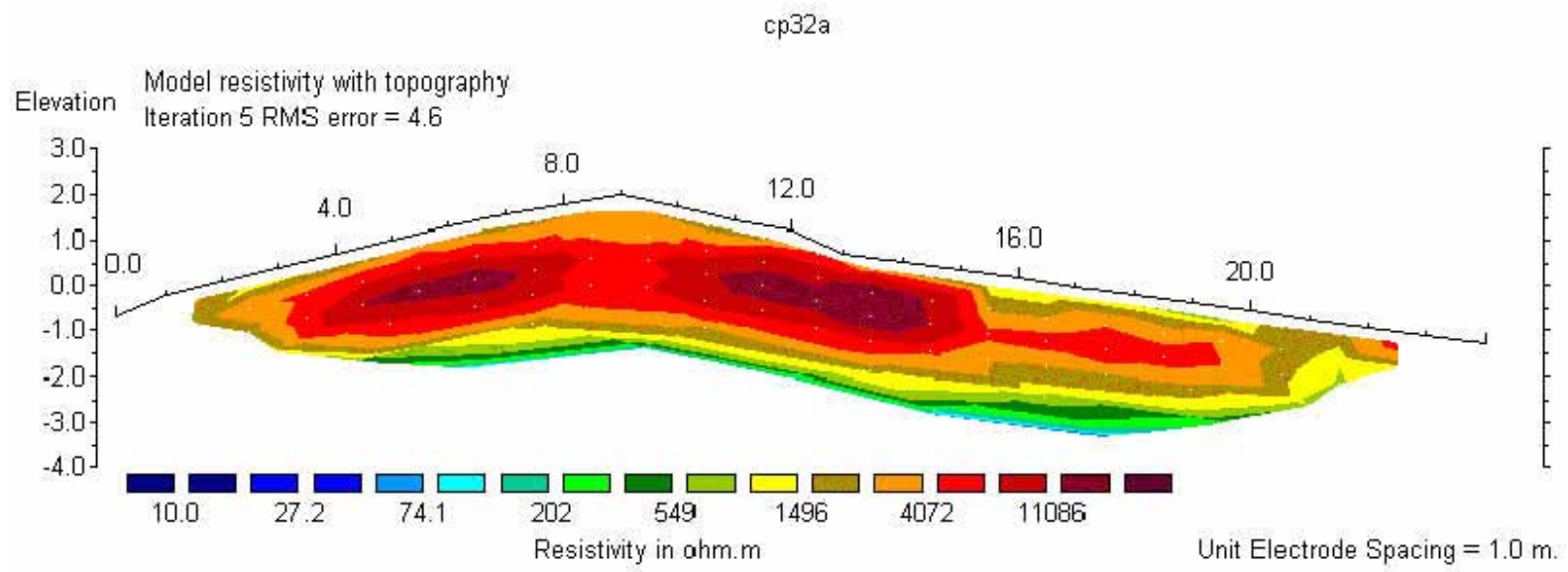

Horizontal scale is 30.42 pixels per unit spacing

Vertical exaggeration in model section display $=0.77$

First electrode is located at $0.0 \mathrm{~m}$.

Last electrode is located at $24.0 \mathrm{~m}$.

Illus 10 Capo Barrow: Profile 32: modelled resistivity cross-section, topographically corrected. North at left side of plot

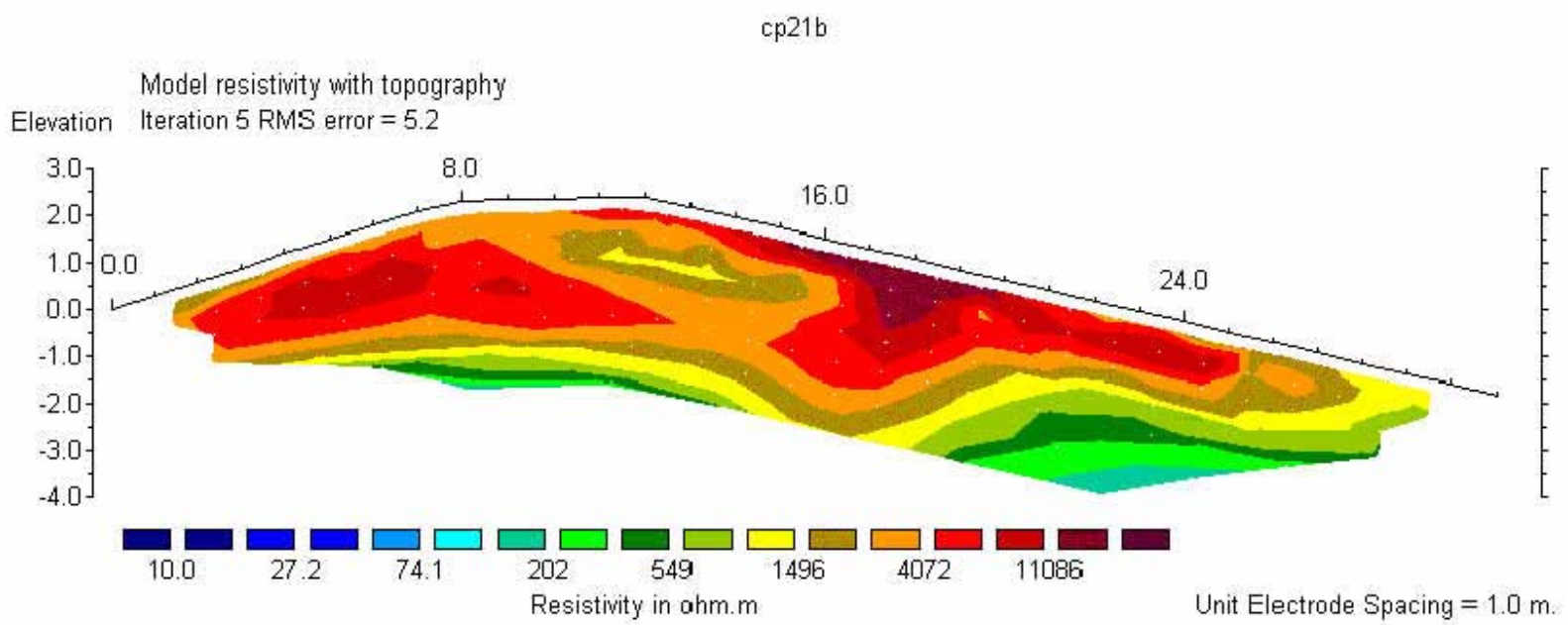

Horizontal scale is 23.55 pixels per unit spacing

Vertical exaggeration in model section display $=1.02$

First electrode is located at $0.0 \mathrm{~m}$.

Last electrode is located at $31.0 \mathrm{~m}$.

Illus 11 Capo Barrow: Profile 21: modelled resistivity cross-section, topographically corrected. North at left side of plot

the measured apparent resistivities, the root mean square (rms) difference being $8.8 \%$. Topography has been used in this calculation and the final model with the topography included is shown in Illus 9. Two high resistivity features dominate the crosssection and are interpreted as the revetments defining the edges of the barrow at $5.5 \mathrm{~m}$ and $13 \mathrm{~m}$ along the profile.

Nearby, profile 32 shows similar features (Illus 10); the revetments are well delineated at $6 \mathrm{~m}$ and $13.5 \mathrm{~m}$. The inversion result for profile 21, midway along the barrow, is shown in Illus 11. The revetments can be seen at $5 \mathrm{~m}$ and $18 \mathrm{~m}$, and in between there is a region with distinctly lower resistivity. Further to the east, profile 15 (Illus 12) shows the revetments lying at $5 \mathrm{~m}$ and $24 \mathrm{~m}$, and in between them a conducting region surrounded by high resistivity. The surrounding high resistivity is suggestive of stones that may have formed part of a stone-defined mortuary structure. Profile 12 (Illus 13) is a further example with a distinct high resistivity block surrounding an area of low resistivity. Similar structure is seen on neighbouring profiles between profile 23 and profile 11 . Either this represents a continuous inner chamber 


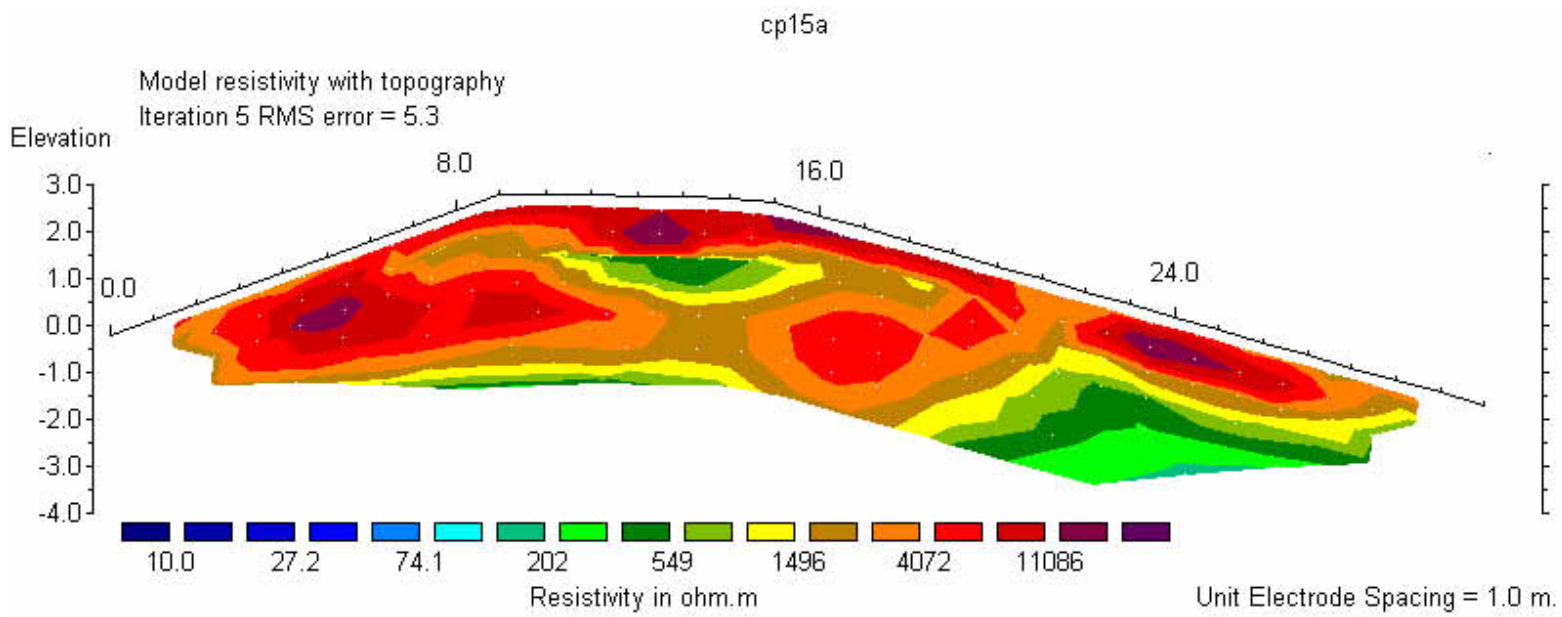

Horizontal scale is 23.55 pixels per unit spacing

Vertical exaggeration in model section display $=1.02$

First electrode is located at $0.0 \mathrm{~m}$.

Last electrode is located at $31.0 \mathrm{~m}$.

Illus 12 : Cappo Barrow: Profile 15: modelled resistivity cross-section, topographically corrected. North at left side of plot

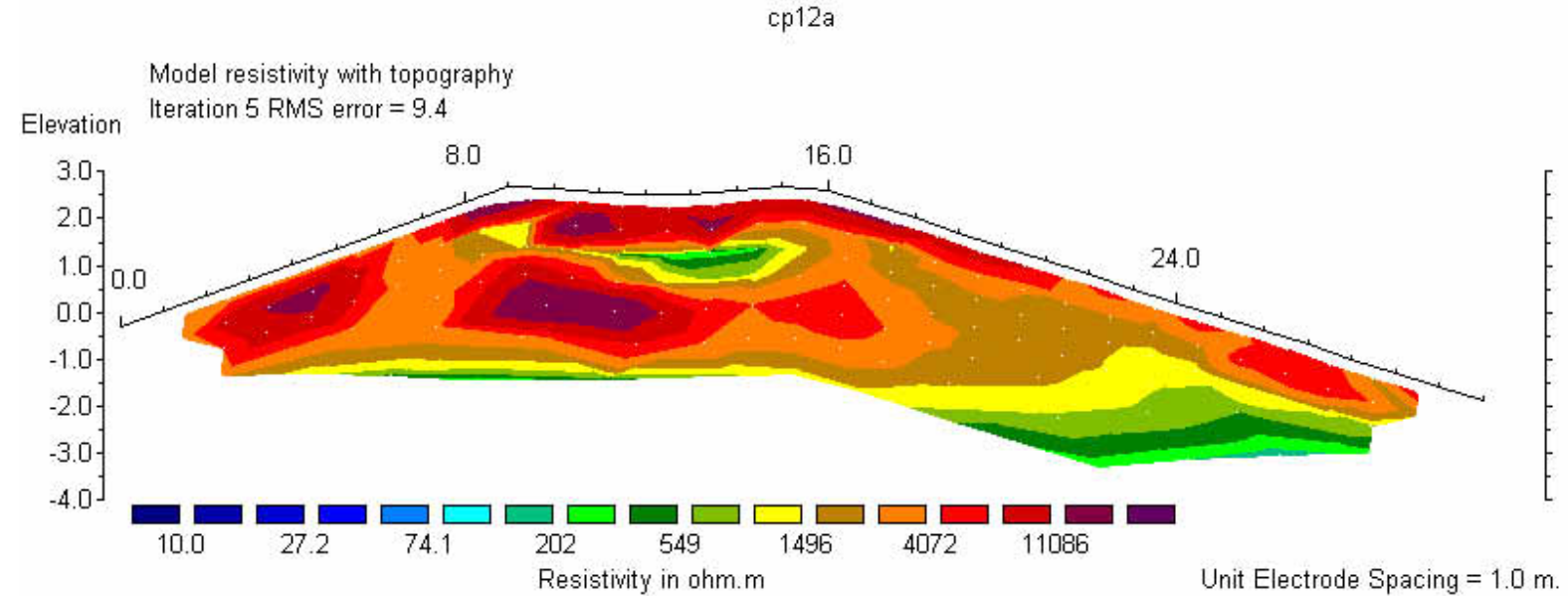

Horizontal scale is 23.55 pixels per unit spacing

Vertical exaggeration in model section display $=1.02$

First electrode is located at $0.0 \mathrm{~m}$.

Last electrode is located at $31.0 \mathrm{~m}$.

Illus 13 Capo Barrow: Profile 12: modelled resistivity cross-section, topographically corrected. North at left side of plot

$24 \mathrm{~m}$ long by $8 \mathrm{~m}$ wide, or individual blocks may be associated with distinct burials.

\subsection{Plan views of resistivity}

An alternative method of presentation, often used when image data has been collected beneath several neighbouring profiles, is to collate all the modelled images and to view horizontal slices of resistivity variations at particular depths (Illus 14-17). The depths are related to an arbitrary datum of $0 \mathrm{~m}$
(Illus 6). The positions of all the profiles surveyed are shown on Illus 6 and the data points (resistivity blocks in the inverted models) that contribute to the horizontal slices at $-0.5 \mathrm{~m}$ are shown on Illus 17 : these can be used to judge a high level of confidence in the features described below. Those parts of the plots of the horizontal slices (Illus 14-17) that lie beyond the ends of the profiles, as shown on Illus 6 , are data-processing artefacts and should be ignored.

Coordinates in parenthesis in the following text relate to the axes on Illus 14-17. Eastings precede 

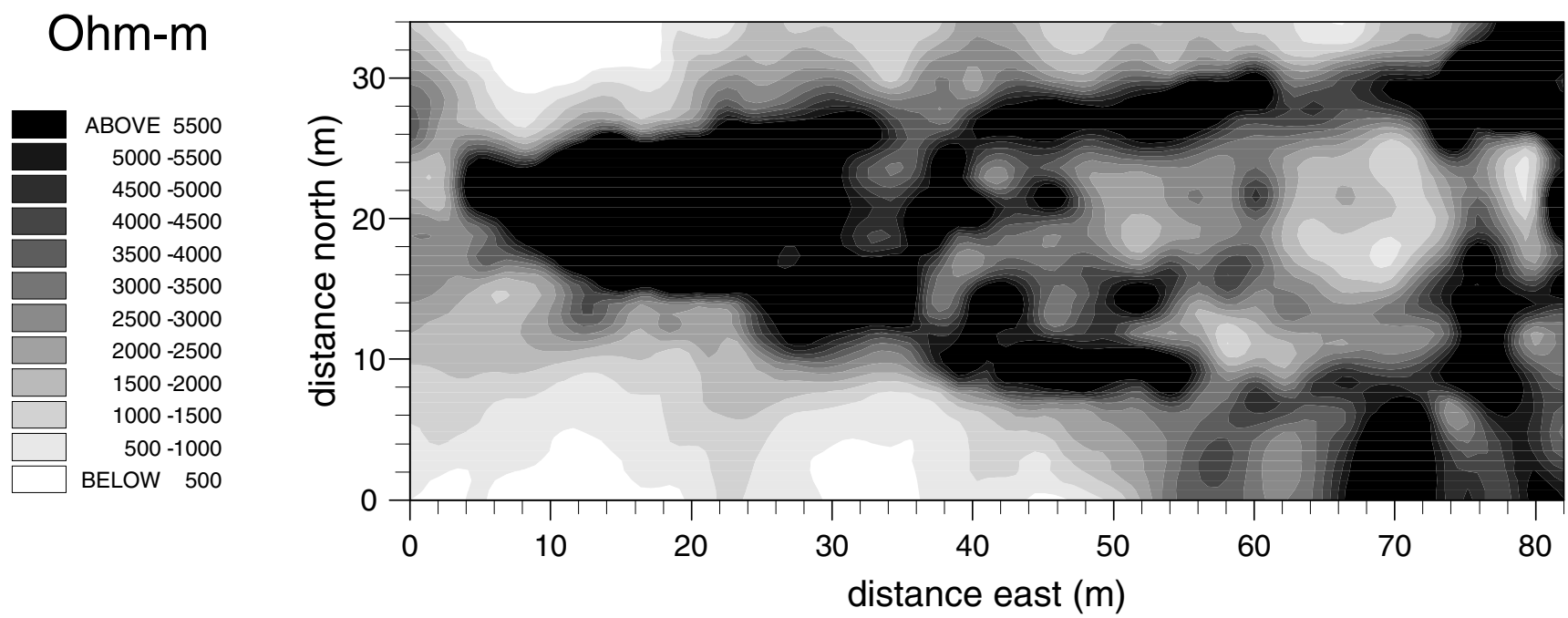

Illus 14 Capo Barrow: Horizontal depth slice through collated modelled images at a datum level of -0.5m (Scale $500 \Omega m-5500 \Omega m$ ). Presented by UNIMAP
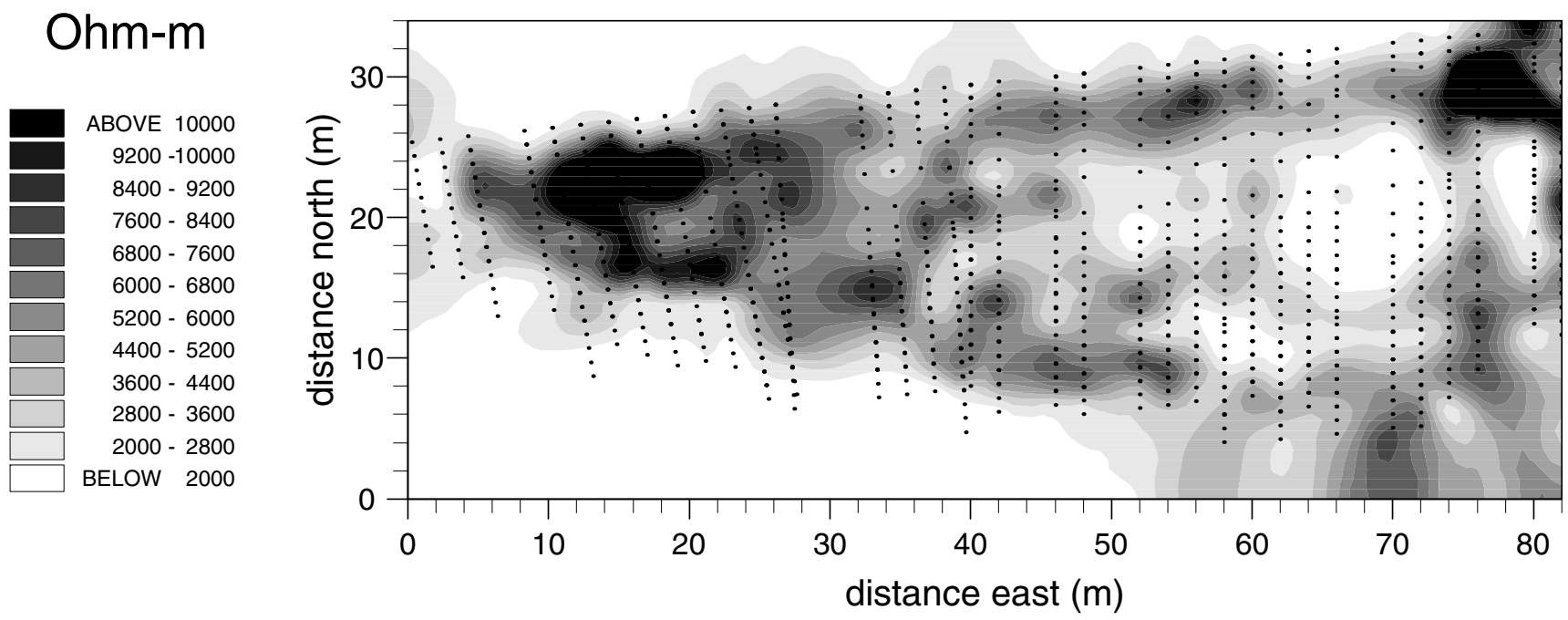

Illus 15 Capo Barrow: Horizontal depth slice through collated modelled images at a datum level of-0.5m (Scale $2000 \Omega m-10,000 \Omega m$ ). Presented by UNIMAP

northings and the units of measurement used are metres.

Illus 14 shows such a horizontal slice through the barrow at $0.5 \mathrm{~m}$ below the datum level. The plan position of the revetments is revealed together with a number of other features. At the wider and taller eastern end of the barrow the side revetments are well-defined narrow regions of high resistivity and the frontal façade is very straight. Gaps in the revetments at $(64,28),(56,8)$ and $(36,26)$ and the façade at $(74,24)$ may be entrances to the barrow, some or all of which could lead to mortuary structures. One of the possible side entrances on the northern side of the barrow, near location $(36,26)$, leads into a low resistance region measuring $c 8 \mathrm{~m}$ by $4 \mathrm{~m}$, which is particularly readily interpreted as a mortuary structure.

Resistivities above $5000 \Omega \mathrm{m}$ collectively appear black and thus the western end of the barrow appears featureless at the scale used in Illus 14 . Detail within this region is provided by a change of scale and Illus 15 shows the same horizontal slice with resistivities ranging from $2000 \Omega \mathrm{m}$ to $10,000 \Omega \mathrm{m}$. At the lower and narrower western end of the barrow a rectangular section with lower resistivity than its surroundings appears at location $(20,20)$. Whilst it is possible that this anomaly may be a mortuary structure, it is equally possible that 

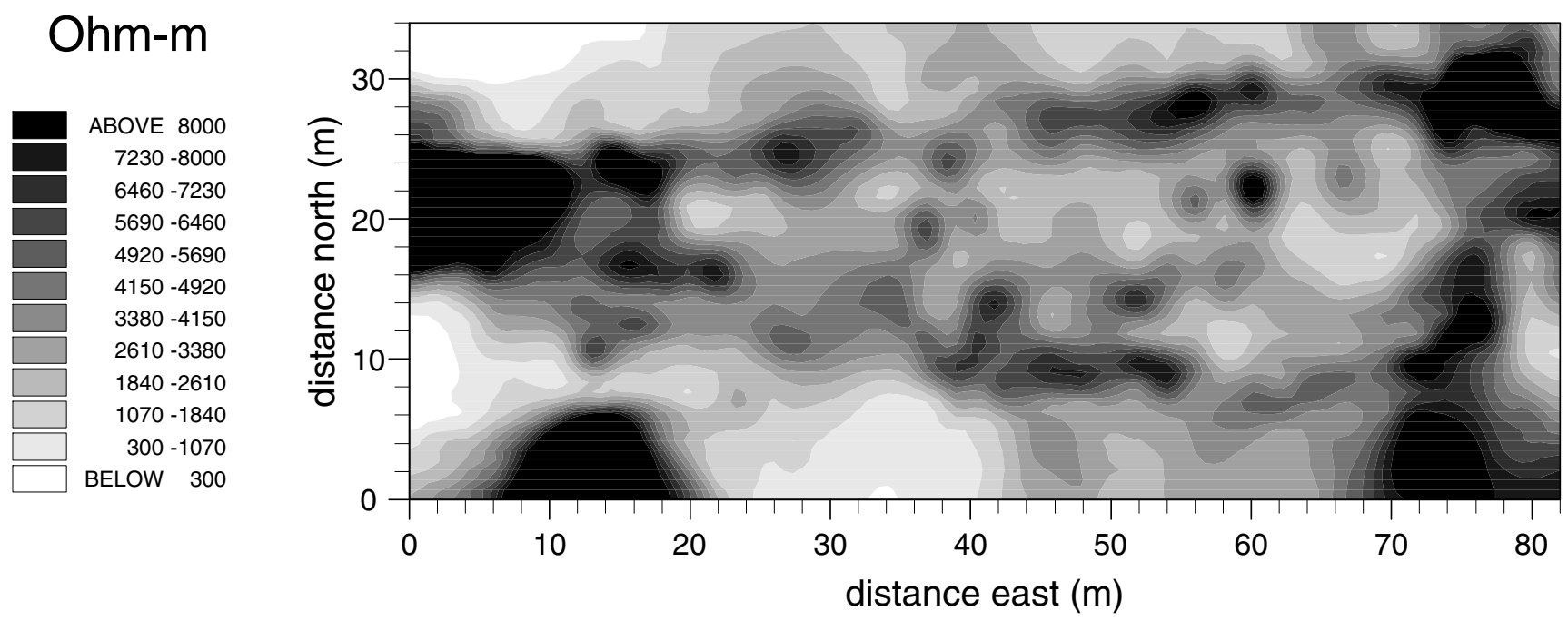

Illus 16 Capo Barrow: Horizontal depth slice through collated modelled images at a datum level of -1.5m (Scale $300 \Omega m-8000 \Omega m$ ). Presented by UNIMAP

\section{Ohm-m}
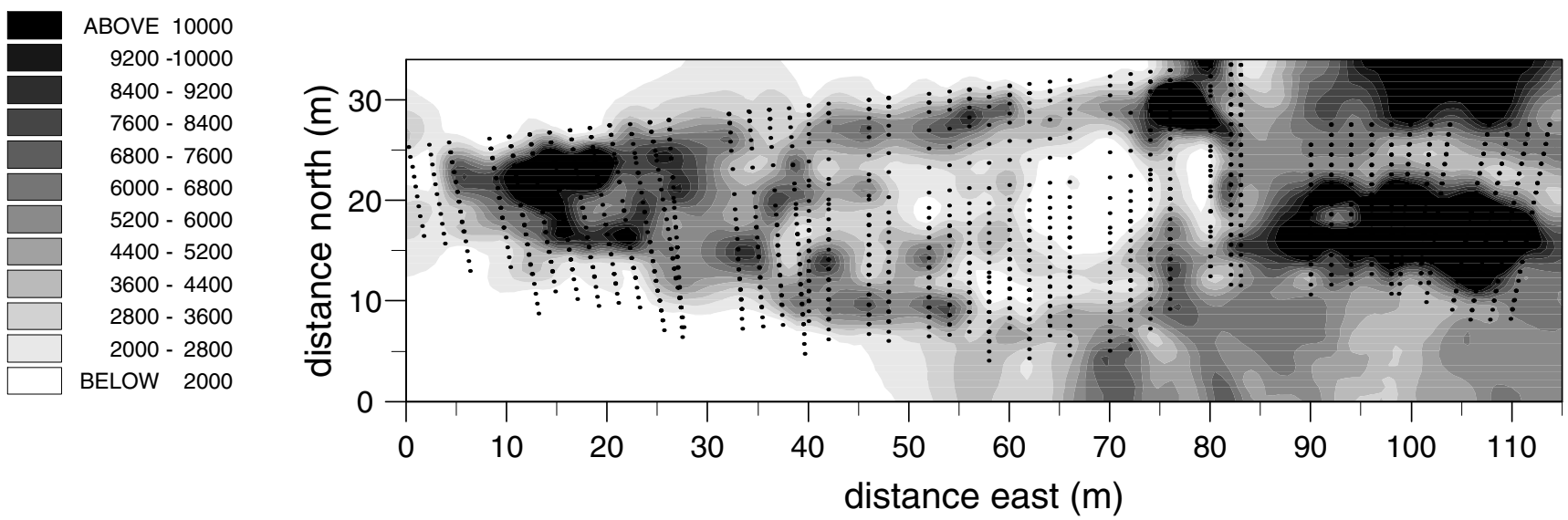

Illus 17 Capo Barrow: horizontal depth slice through collated modelled images, including the small mound to the east of the barrow, at a datum level of $-0.5 \mathrm{~m}$ (Scale $2000 \Omega \mathrm{m}-10,000 \Omega \mathrm{m}$ ). Presented by UNIMAP

the surrounding areas of high resistivity are the response from the revetments at the western end of the barrow.

Examination of all the vertical cross-sections of modelled resistivities shows the revetments to lie approximately $1.5 \mathrm{~m}$ below datum level to the west, rising to about $0 \mathrm{~m}$ to the east. This suggests an inclined plane as the ground surface prior to the construction of the barrow. A slice through the resistivity data at $1.5 \mathrm{~m}$ below datum level is shown in Illus 16. At this depth, the side revetments at the lower, western end of the barrow can be seen clearly as well defined areas of high resistivity. A similar area of low resistivity to that on Illus 15 can be seen at around $(20,20)$, but is less readily interpreted as a mortuary structure at this depth.

\subsection{The mound to the east of the barrow}

Following the main survey, a further 13 resistivity profiles were taken to the east of the barrow, in front of the presumed entrance and over the low mound. Collating all 48 profiles and selecting a horizontal slice at $0.5 \mathrm{~m}$ below datum results in Illus 17 . A distinct high resistivity region is seen extending from the barrow entrance. Note the change of resistivity scale in comparison with Illus 14 to accommodate the higher resistivities seen outside the barrow. The results of the resistivity survey over the low mound to the immediate east of the barrow cannot be used to argue either for or against an anthropogenic origin for this feature. 


\section{Conclusions by Lindsey Collier, Bruce Hobbs, Tim Neighbour and Richard Strachan}

The programme of fieldwork at Capo Long Barrow has considerably enhanced our knowledge of this monument. Topographical survey, conducted in 1998, has provided the first detailed record of the barrow and its environs. Resistivity survey, carried out in summer 1999, has been successful in revealing key elements of the structure of the barrow, including side revetment walls, a flat frontal façade and possible mortuary structures, confirming that the barrow at Capo is of a similar morphology to the nearby barrow at Dalladies, excavated by Piggott (Piggott 1974).

Topographical survey demonstrated that the barrow was built with its southern side along the edge of a low ridge, presumably to make it appear taller when viewed from the south. The careful placement of barrows in relationship to natural features is commonplace in the Neolithic (Bradley 1993; Lynch 1997; Kinnes 1992).

At most depths the side revetments are clear as high resistivity anomalies (Illus 15, 16 \&17). The revetments at the lower, rear of the barrow can only be seen on the lowest horizontal slice (Illus 16). The resistivity of the material contained by the revetment walls is consistent with interpretation as a similar earth and rubble core to that discovered at Dalladies (Piggott 1974, 27-28 \& fig 4). At least some of the breaks which have been recorded in the revetments at $(64,28),(56,8)$ and $(36,26)$ and the frontal façade at $(74,24)$ are likely to be entrances into mortuary structures within the barrow. The break in the northern side revetment at $(64,28)$, close to the front of the barrow, is in a similar position to the mortuary structure discovered at Dalladies (Piggott 1974, fig 3). A further convincing mortuary structure, measuring c. $8 \mathrm{~m}$ by $4 \mathrm{~m}$ has been revealed on the northern side of the barrow, closer to the rear at $(36,26)$. The possibility that a further chamber lies at $(20,20)$ at the rear of the barrow should not be discounted.

The resistivity survey has demonstrated that rabbit burrowing and the roots of the tree stumps that covered the barrow have had little effect on the integrity of the major structural elements of the monument (the revetments and façade). However, it is not possible to assess the more subtle damage, such as mixing of archaeological layers, which may have been caused.

Resistivity imaging at the survey density employed at Capo Long Barrow is time-consuming and would not generally be appropriate if excavation were to be carried out. However, as a management tool and as a means to explore sites that are unavailable for excavation, such as scheduled ancient monuments, it has been demonstrated here to be of considerable value. Area resistivity or gradiometry, as traditionally applied to archaeological sites (Clark 1996), would not have attained the depth penetration that was achieved by resistivity imaging and would have been logistically difficult in the terrain at Capo. 


\section{Acknowledgements}

The fieldwork at Capo was funded by Historic Scotland and the Department of Geology and Geophysics, University of Edinburgh. The project was carried out as part of The Angus and South Aberdeenshire Field School of the Department of Archaeology, University of Edinburgh. The illustrations that accompany this report were prepared by George Mudie, who was funded by Historic Scotland. The photographs of Capo Long Barrow (Illus 3) were taken by Gordon
Barclay. The authors are grateful to Patrick Ashmore, Gordon Barclay, Ian Ralston, the SAIR Pilot Editor and his two referees for comments on earlier drafts of this report. Whilst thanks are due to all of the above, final responsibility for any errors lies with the authors, CFA Archaeology Ltd and The Department of Geology and Geophysics, University of Edinburgh. 


\section{References}

Barclay, G J and Shepherd, I A G 1989 'Capo (Fettercairn parish), earthwork', Discovery Excav Scot 1989, 23.

Barlow, A J and Geldart, J R 1978 'Capo farm, flints', Discovery Excav Scot 1978, 31.

Bradley, R 1993 Altering the Earth. Edinburgh ( = Soc Antiq Scot Monograph 8).

Bryce, T H 1903 'On the cairns of Arran - a record of further exploration during the season of 1902', Proc Soc Antiq Scot 37 (1902-3), 36-67.

Clark, A 1996 Seeing Beneath the Soil: Prospecting Methods in Archaeology. London.

Clark, J G D 1932 'The Date of the Plano-Convex Flint-Knife in England and Wales', Antiq $J 12$ (1932), 158-62.

Finlayson, B, Coles, G, Dunwell, A \& Ralston, I 1999 'The Angus and South Aberdeenshire Field School of the Department of Archaeology, University of Edinburgh - research design', Tayside and Fife Archaeological Journal 5 (1999), 28-35.

Henshall, A S 1963 The Chambered Tombs of Scotland: Volume 1. Edinburgh.

Henshall, A S 1972 The Chambered Tombs of Scotland: Volume 2, Edinburgh.

Kinnes, I 1992 Non-Megalithic Long Barrows and Allied Structures in the British Neolithic. [ = British Museum Occasional Paper 52].

Loke, M H and Barker, R D 1995 'Least-squares deconvolution of apparent resistivity pseudosections', Geophysics 44 (1995), 131-52.
Lynch, F 1997 Megalithic Tombs and Long Barrows. Princes Risborough.

Marshall, A 1998 'Neolithic Long Barrows: Use of Integrated Remote Sensing at High Resolution to Establish General Layout and Detect Foreground Structure' Archaeological Prospection 5 (1998), 101-16.

Neighbour, T, Strachan, R \& Hobbs, B A 2001 'Resistivity Imaging of the Linear Earthworks at the Mull of Galloway, Dumfries and Galloway', Archaeological Prospection 8 (2001), $157-62$.

Pierpoint, S 1980 Social Patterns in Yorkshire prehistory, 3500-750 BC. Oxford: [ = Brit Archaeol Rep Brit Ser 74].

Piggott, S 1970 'Capo farm: long barrow', Discovery Excav Scot 1970, 27-28.

Piggott, S 1974 'Excavation of the Dalladies long barrow, Fettercairn, Kincardineshire', Proc Soc Antiq Scot 104 (1971-72), 23-47.

Piggott, S and Powell, T G E 1951 'The Excavation of Three Neolithic Chambered Tombs in Galloway, 1949', Proc Soc Antiq Scot 83 (1948-1949), 103-61.

RCAHMS 1982 The Archaeological Sites and Monuments of South Kincardine, Kincardine and Deeside District, Grampian Region. Edinburgh.

Walker, A D, Campbell, C G B, Heslop, R E F, Gauld, J H, Laing, D, Shipley, B M \& Wright, G G 1982 Soil and Land Capability for Agriculture. Eastern Scotland. Aberdeen. 